\title{
The Improving Students' Mathematics Results and Interest Through Online-Based Flipped Classroom Models
}

\author{
Hamidah $^{*}$ E Jaka Wijaya Kusuma \\ Department of Mathematics Education, Universitas Bina Bangsa, Serang, Indonesia, 42116 \\ *Corresponding author: hamidah@binabangsa.ac.id | Phone Number: +6289693492174
}

\section{ARTICLE HISTORY}

Received : 24 September 2020

Revised : 15 December 2020

Accepted : 8 April 2021

\section{KEYWORDS}

Interest;

Mathematics Result;

Flipped classroom;

Online learning;

\begin{abstract}
People know that the internet today has become an integral part of the lifestyle of various Indonesian community groups, but the results of surveys conducted by the Indonesian Internet Network Organizing Association are known to have access to educational pages are still very lacking. The online-based flipped classroom learning model is packaged to appeal to students and is a learning that adapts online learning in times of pandemic by directing students to utilize the internet for learning. This study was a classroom action research by applying online-based flipped classroom model to improve Students' Mathematics Result And Interest. The classroom action research was done in two cycles. Each cycle consists of planning, action, observation, and reflection. The findings of this research revealed that the online-based flipped classroom model could improve students' mathematics results and interest. At the end of the first cycle, the students' mathematics result was still in the medium category and increased at the end of the second cycle, which students' mathematics result has been in high category, and students' mathematics interest has been more than $80 \%$ that is reaching the expected target.
\end{abstract}

This is an open access article under the CC-BY-SA license.

\section{INTRODUCTION}

Referring to the current spread of Covid 19, online learning is one of the solutions chosen by the government to continue learning and teaching activities throughout the Republic of Indonesia. According to (Naserly 2020) not only at the basic level but online learning is set thoroughly to all levels of education up to the college level. As reported by Republika.co.id (Wednesday 25 Mar 2020 01:36 WIB) by Nadiem Makarim, the minister of education and culture mentioned that online learning automatically makes teachers and students required to try and further explore learning technology.

On the other hand, it is known that the internet today has become an integral part of the lifestyle of various Indonesian community groups. According to (Saifuddin, 2017) the data of the survey conducted by the Indonesian Internet Network Organizing Association (APJII) in 2016 shows that among students is the largest internet user in Indonesia, namely students in the first order $89.7 \%$, and the second place students with $69.8 \%$, but it is known that access to education pages is still very lacking. Furthermore, based on the results of apjii survey in 2018 it is known that the main reason for using the internet is communication and social media, and known content that is often visited is to watch movies /videos. Based on the results of research (Wayan Ilia Yuda Sukmana and Kadek Suartama 2018) it is known that students are less required to utilize technological developments for learning and teachers are less utilizing technology in the implementation of learning process. Furthermore according to (Tsai et al. 2018) online learning can create an environment that engages students in ways that will maintain their high interest and commitment to continuing learning. So there still needs to be awareness from students and teachers in making the most of technology (Kusuma \& Hamidah 2019a).

Based on the results of research (Jaka Wijaya Kusuma and Hamidah 2019b) it is known that the learning model used greatly influences students' learning interests to engage during the learning process. Furthermore, the interest in learning greatly influences the results of learning. The results of the study (Boriri and Ishak 2020) show that student interest in learning is quite influential on learning achievement. From the results of the analysis it can be said that the greater one's learning interest, the higher the learning achievement. But in fact, online learning today still seems unprepared and less attentive to students' learning interests. Based on the results of interviews with students it is not uncommon for teachers to focus on completing material targets regardless of the obstacles faced by students in their learning process. Moreover, there are limitations and constraints in online learning such as unstable signals that reduce the learning time that has the potential impact on the delivery of less optimal materials (Kusuma \& Hamidah, 2020).

Based on the results of the dissemination of pre-research questionnaires to students about online learning is known some things that are urgent and need immediate treatment because it has a very influential effect on student learning 
outcomes. Some of them are $32 \%$ students answering the question "what difficulties exist when participating in online class" is material understanding, $59 \%$ of students answer the question "do you understand the material given during online learning" is lacking and do not understand, and based on the results of live interviews with students it is known that during online learning time it feels brief because sometimes it is difficult to enter the study room and not rarely left behind discussion material. Students also stated that not a few lecturers give a lot of assignments without providing a detailed explanation of the material. This is also supported by the results of research (Riyanda, Herlina, and Wicaksono 2020) known that several factors causing online learning results have not reached targets including limited understanding and ability of educators in online learning, unstable internet connections, and the unpreparedness of educators for updates in the online learning system. The results of the study (Riyanda, Herlina, and Wicaksono 2020) are also known that there are still educators who need to improve their competence in the implementation of online learning.

Departing from the above facts, it is necessary to have a suitable learning model to adjust online learning during this pandemic while also considered able to attract interest as well as improve student learning outcomes. According to (Korhonen, Ruhalahti, and Veermans 2019) a teacher should consider whether the chosen model includes pedagogical elements, otherwise he or she may need to devote more attention to students during the learning process. The statement was also confirmed by (Ernest 2019) that teachers or lecturers can make relevant findings and apply to their own subjects, thus becoming professional teachers. Professional teachers are the key to the success of mathematics learning. Teacher professional knowledge consist of content knowledge, pedagogical content knowledge, and general pedagogical knowledge. Pedagogic content knowledge is an understanding about representations, analogies, examples of mathematical concepts, and skills on how to teach students mathematics. For that one suitable learning model is flipped classroom based online (Kusuma \& Hamidah 2019a).

According to (Sukmana and Suartama, 2018) flipped classroom learning model is teaching strategy by minimizing the number of direct instructions and maximizing interaction with each other. According to (Elmaadaway 2018) content in a flipped classroommay be delivered to students via prerecorded or live video lectures, audio recordings, screencasts, annotated notes, automated tutoring systems or computer simulation programs. Furthermore, the results of the study (Mirlanda, Nindiasari, and Syamsuri 2020) are known that with the flipped classroom learning model, teachers can effectively spend time interacting with students and help them resolve difficulties in understanding concepts and accommodate each student's ideas.

The flipped classroom learning process is based online, previously students were required to view certain learning videos, websites or tutorials that have been determined/prepared and can be accessed through their internet-connected mobile phones/computers. The material that is first provided through text, audio, video, animation, or multimedia learning must be studied by students in their own home and work on the prepared questions. Instead, classroom study sessions are used for discussion. In this study flipped classroom based online, the meaning is a study session for discussion in the classroom conducted online. This is expected to overcome time and signal limitations during online learning while increasing students' interest and learning outcomes. According to (Vermana and Zuzano, 2018) with flipped classroom learning students are required to study and read books at home before learning begins. Furthermore, when online students just discuss asking questions that are less or not understood.

Based on the above, the authors are interested in conducting research by applying an online-based flipped classroom learning model to improve students' interest and math learning outcomes. The purpose of this study is to find out: 1) how Students' Mathematics Result improve with an online-based flipped classroom model; and 2) how to Students' Mathematics interest after learning with flipped classroom models based online.

\section{METHODS}

This type of study is class action research. Class action research is action research conducted with the aim of improving the quality of learning practices in its classroom (Vermana and Zuzano 2018). Research was conducted in the lecture class of mathematics education study program of Bina Bangsa University in the even semester of the academic year 2019-2020. The subjects of the study were students of the mathematics education study program who participated in the field of geometry analytics space numbering 38 students.

Class action research is carried out in several cycles, each cycle consisting of four stages namely the stage of planning, action execution, observation, and reflection. In general the class action research steps as in the following figure:

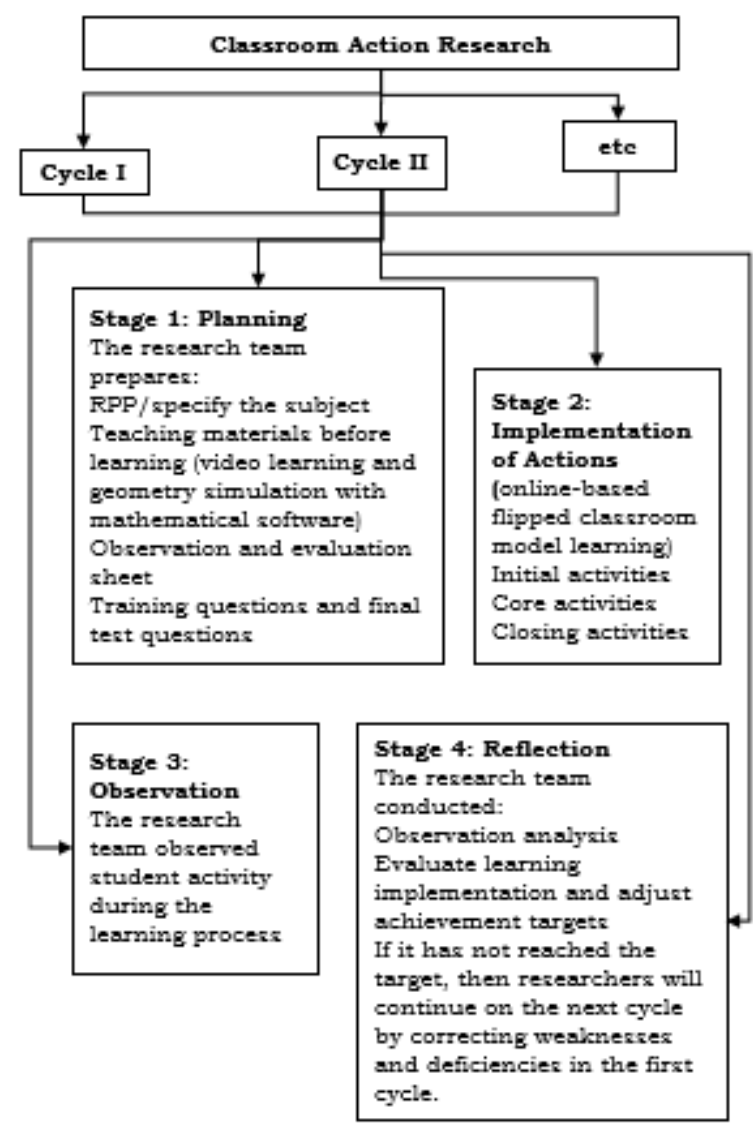

Fig. 1. Research measures 
At the planning stage the research team prepared a cone slice material in the form of a learning video. In the learning video is also shown simulation with mathematical software namely geometry pad to make it easier for students to understand the material while attracting students to the material provided. Students are also given youtube links through whatsapp group as an additional reference in understanding the material. At the end of the learning video is also prepared about training for students to work at home and discussed during the implementation of learning. Furthermore, at the stage of implementation of the action, the online learning process with flipped classroom model is done via zoom i.e. discussing the difficulty of students in understanding the material or resolving the training question given. The observation stage is that the teaching lecturer as a researcher accompanied by the research team will fill out an observation and evaluation sheet during the online learning process by observing the activities of lecturers and students. The reflection stage is that the research team analyzes the observation results and evaluates the learning process. If the results and learning process have not reached the target then the researchers make improvement points to apply to the next cycle.

The instruments used to collect data on this study are the study interest questionnaire and the study results test. Interest indicators to be observed include student attitudes that show a sense of pleasure while studying, attraction/perseverance during the learning process, attention to lessons, and involvement/active following learning. While the study results used in the study is the final test of cone slice material given after learning is given in the form of a description test.

The data analysis technique of the students' mathematics result in this study is to determine the percentage of classical completion of students who have a $\mathrm{C}+$ equivalent grade (grade 65 on a scale of 100) upwards on the quiz of each cycle calculated by using the following formula (Yuliawati 2019):

$$
\text { Percentage }=\frac{\text { Number of Students with grades above } 65}{\text { Total Students }} \times 100 \%
$$

The percentage of classical completion for students' mathematics result in space geometry courses is $\geq 85 \%$ of students achieve grades above 65 .

For data students' mathematics interest is analyzed by being classified in the categorization table. Study interest poll scores range from 30 to 150 . To determine the criteria for measurement results are classified based on average, namely:

$\left(\bar{x}=\frac{30+150}{2}=90\right)$ and deviation standards $\quad\left(s=\frac{150-30}{6}=20\right)$.

Categorization of measurement results using criteria developed by (Sunendar, 2016) can be seen in the following table.

Table 1. Learning Interest Qualifications

\begin{tabular}{ccc}
\hline Score Interval & Score & Category \\
\hline$X>\bar{x}+1,5 s$ & $X>120$ & Very high \\
\hline $\bar{x}+s<X \leq \bar{x}+1,5 s$ & $100<X \leq 120$ & High \\
\hline $\bar{x}-0,5 s<X \leq \bar{x}+s$ & $80<X \leq 100$ & Enough \\
\hline $\bar{x}-1,5 s<X \leq \bar{x}-0,5 s$ & $60<X \leq 80$ & Low \\
\hline$X \leq \bar{x}-1,5 s$ & $X \leq 60$ & Very Low \\
\hline
\end{tabular}

The resulting data of the student's study interest category is then calculated the percentage of classical completion that is students who have a high or very high learning interest after being given learning calculated by using the following formula (Yuliawati 2019):
Percentage $=\frac{\text { Number of Students with high interest categories and very high }}{\text { Total Students }} \times 100 \%$

The percentage of classical completion for student learning interests is $\geq 80 \%$ of students have a high and very high learning interest after learning.

\section{RESULTS AND DISCUSSION}

\subsection{Results}

This research was conducted in 2 cycles, each cycle was conducted as many as 3 meetings according to the learning schedule. The following are presented the findings on student learning results in cycles I and II after being given learning with flipped classroom models based online.

Table 2. Student Learning Results Cycle I and II Descriptive Statistics

\begin{tabular}{cc|c|c|c|c|c|c}
\hline & $\mathrm{N}$ & Min & Max & Mean & SD & Var \\
\hline Cycle I study results & 38 & 56 & 85 & & 69.74 & 8.85 & 78.36 \\
\hline Cycle 2 study results & 38 & 62 & 88 & 77.13 & 7.89 & 62.28 \\
\hline Valid N (listwise) & 38 & & & & & \\
\hline
\end{tabular}

From table 2 it is known that student study results in cycle I averaged 69.74 then increased in cycle II with an average of 77.13. The minimum and maximum values also increase from cycle I to cycle II. Furthermore, from the study data it is known that in cycle I there are 27 students from all students getting grades over 65 or in other words $71.05 \%$ of students reach the target. While in cycle II of 38 students there are 34 students with grades over 65 or in other words $89.47 \%$ students reach the target.

The next table will be presented the results of student learning interests after being given learning with flipped classroom models based online.

Table 3. Student Learning Interests

\begin{tabular}{cccccc}
\hline $\begin{array}{c}\text { Learning } \\
\text { Interest } \\
\text { Criteria }\end{array}$ & $\begin{array}{c}\text { Percentage of Each Learning Interest Indicator (\%) } \\
\text { Pleasure }\end{array}$ & Attention & Interest & $\begin{array}{c}\text { Student } \\
\text { Engagement }\end{array}$ & Total \\
\cline { 2 - 5 } Very High & 5 & 3 & 1 & 4 & 13 \\
\hline High & 17.5 & 19 & 21 & 24 & 81.5 \\
\hline Enough & 2 & 1 & 1.5 & 1 & 5.5 \\
\hline Low & 0 & 0 & 0 & 0 & 0 \\
\hline Very Low & 0 & 0 & 0 & 0 & 0 \\
\hline
\end{tabular}

Table 3 shows that the percentage of study interest of the majority of students is at a high criterion of $81.5 \%$. Then the percentage on the high criteria coupled with the very high criteria reaches $94.5 \%$. In other words, based on the percentage of classical completion for student learning interest has been more than $80 \%$ that is reaching the expected target. Furthermore, the research team's observation data on student activities during the learning process. 


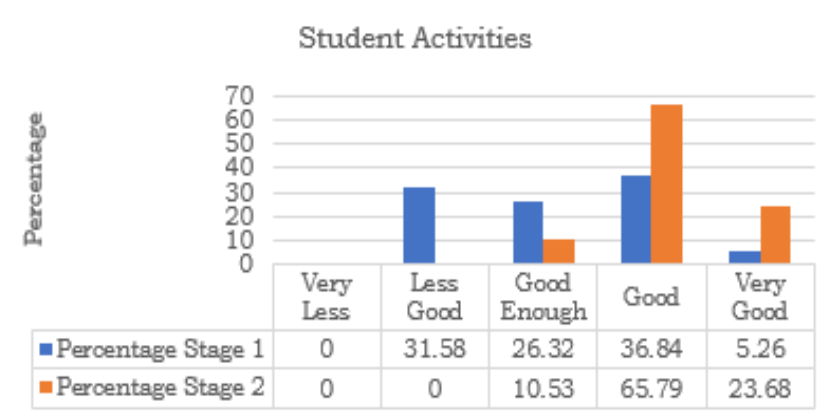

Figure 2. Percentage of Student Activities

Figure 2 is an observation that shows that student activity during the learning process in each cycle has improved for the better. The average percentage of student activity in cycle I reached $42.11 \%$, and increased in cycle II by $89.47 \% .47 .36 \%$ increase in student learning activeness in cycle I and cycle II. In the picture it is also shown that students whose activities are not good in cycle I no longer exist in cycle II. This is because of the observation and evaluation of deficiencies in cycle I so that in cycle II is applied a way to correct the deficiency.

The next figure will be showing the work of students in solving geometry problems after learning is given.

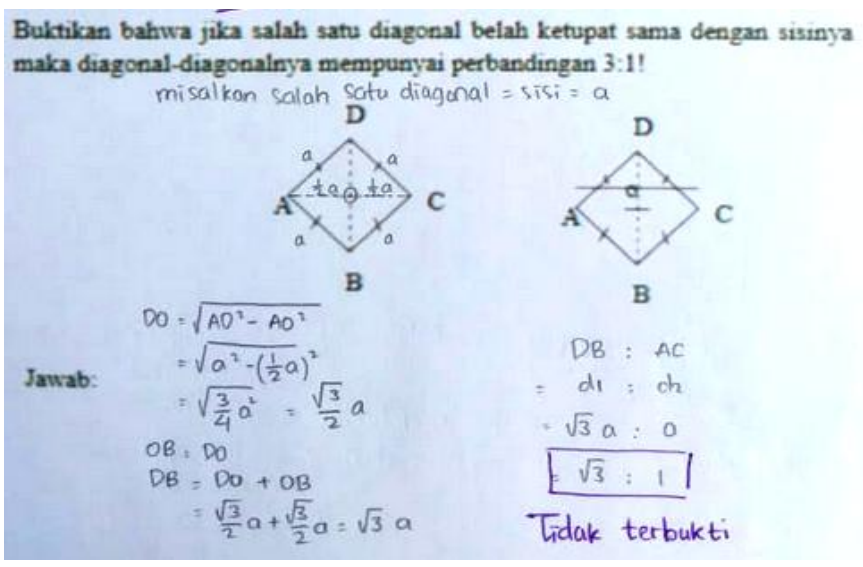

Figure 3. Answer Sheet

\subsection{Discussion}

In table 2 shows that in general, student learning outcomes after taking part in online-based flipped classroom models increased by a percentage exceeding the expected target. This is in line with the results of the study (Mirlanda, Nindiasari, and Syamsuri 2020) namely with flipped classroom learning model can improve the mathematical reasoning skills of high school students grade X. Furthermore in line with the results of the study (Vermana and Zuzano 2018) which is known that the learning model fipped classroom with a strategy of giving questions and getting answers can improve student learning outcomes.

During flipped classroom learning based online students are required to understand the material first before the learning process, thus making students more active when learning online. According to (Cheng, Ritzhaupt, and Antonenko 2019) it is important to use the right strategies to ensure students will learn before face-to-face classes in the implementation of flipped classroom learning. So it was found that almost all students already have a supply of materials and various questions that have been had during the discussion(Negara et al. 2020).
The paradigm of online learning is no longer learning that seems to only give assignments online, but it becomes a solution to invite students more interactive during learning. As said (Panigrahi, Srivastava, and Sharma 2018) that online learning is beneficial for students as they can learn at their own pace with the availability of online materials. This can clearly be seen in the interaction chart that students know shows the better activity in each cycle. Students are active in expressing ideas or questions to their friends. Lecturers continue to monitor and direct discussions so that learning time is used to the maximum for discussion of understanding the material or solving existing problems.

With online learning is able to increase interactivity and learning efficiency because it gives students higher potential to communicate more with lecturers, colleagues, and access more learning materials. This is in line with the opinion (Wong et al. 2019) that emerging technology constantly expands for online learning and continues to fuel the evolution of distance education. The Findings showed a $47 \%$ increase in online learning and blended courses in the primary and secondary education.

Based on the observation results at 3 meetings in cycle I found several deprivation points that need to be corrected, among others: 1) out of 38 students found 21 students who did not ask, 10 students were less involved during the learning process, 12 students who could not answer questions given by lecturers or classmates, and 11 students expressed lack of understanding of the material submitted. According to (Rizqulloh 2020) as a lecturer should be able to read the situation and understand the needs of students in the learning process. Thus, the improvements made in cycle I and applied to cycle II are: 1) require students to make a summary of the material from the learning video provided before the learning process begins, 2) require students to make what points are known and unknown from the learning video, and 3) require students to make questions either to ask the lecturer or discussed with classmates.

Findings in cycle 2 showed that student activity increased significantly by $47.36 \%$. After rpp observation and improvement, students in addition to being required to understand the material before learning, they are also used to making summaries and question points around the material from the given video. Although observations in cycle II show there are $10.53 \%$ of students who still show less involvement and less interactive. This is because students still seem embarrassed to express their ideas, especially the material that they have still lacking. According to (Ayçiçek and Yelken 2018) despite the advantages of the flipped classroom model there are some drawbacks that may occur when students do not watch videos before learning.

But activities during the learning process in general have been very communicative, each student has questions to discuss and has a summary of the material as the basis for answering questions during the discussion. This is in line with the opinion (Wayan Ilia Yuda Sukmana and Kadek Suartama 2018) which mentions that the flipped classroom learning process invites active students to discover themselves the essence of the subject matter. Further according to (Akçayır and Akçayır 2018) in flipped classrooms, students experience active learning and have opportunities to perform higher order thinking activities. So students must indirectly engage in the learning process and its positive impact on fostering confidence and developing intellectual ability. 
Figure 3 shows that the results of teaching with flipped classrooms models help students to understand geometry materials well. From the answer sheet, students are seen parsing and writing info from the question into neatly arranged answer pieces, so that the direction of the answer becomes clear. The results of the evaluation analysis on teaching also showed the ability to argue well when asked to explain the answers to the results of the question practice. Students also utilize the math software provided to understand the material and solve the given problem.

According to (Itqan 2018) learning by utilizing technology goes hand in hand with students' learning interests. The same is also revealed by (Dina, Ikhsan, and Hajidin 2019) that the importance of developing an interest in learning mathematics. According to him that if students have the pleasure of learning mathematics and positive responses to mathematics, difficult math lessons become easy for them, so that enthusiastic students in learning math and mathematical concepts will be attached to their minds. This is evidenced by the results of this study which showed a large interest in studying students with online learning which is $81.5 \%$ students showed high interest after being given online learning with flipped classroom models.

Students' interest in lessons also has a positive impact on their learning outcomes. Known from cycle I then cycle II shows improved student learning outcomes after learning. This shows students follow the learning circuit well. The observations showed that each student tried to stand out in expressing his questions and ideas during the discussion. According to (Triarisanti and Purnawarman 2019) learners who are interested in a lesson will have broad knowledge of the lessons and get benefits from learning in everyday life. So it is very important to pay attention to students' learning interests during the learning process.

In its application, flipped classroom model utilizes mathematical software namely geometry pad so that the material conveyed becomes more interesting and easy to understand. According to (Yani and Rosma 2020) states that technology is very useful in simulation, multimedia, and modeling. Students are also given youtube links as a reference for the material to be discussed. Thus the student's knowledge becomes more extensive and open, especially students do not feel bored with the learning process. This is in line with the opinion (Jaka Wijaya Kusuma and Hamidah 2019b) that one way to attract students' interest and attention in learning is to provide variation in the learning process.

Further during the learning process, students are directed to create groups to facilitate and facilitate discussion. Thus the discussion is continued through chat via group even though the learning time is up. This coordinates the difficulties of unfinished students during discussions during learning. This is in accordance with the results of the study (Mulenga and Marbàn 2020) has shown that social media use in learning instructions, by and large improves the nature of teaching. Whatsapp groups other than to discuss are also used as a means to convey information either in the form of the delivery of the next material or the reference link of the material for the next meeting.

However, there are still some students who experience a problem with online-based learning. Based on the results of live interviews, students expressed more familiar with direct learning. According to students, there is pressure during online learning so that the material provided becomes elusive. This is reinforced by the results of research (Istikomah and Wahyuni 2018) who reported students who are common with gadgets as a learning medium still have high anxiety in learning mathematics, and be concluded that gadgets do not significantly contribute to the level of mathematics anxiety.

\section{CONCLUSION}

The findings of this research revealed that the online-based flipped classroom model could improve Students' Mathematics Result And Interest. At the end of the first cycle, the students' mathematics result was still in the medium category and increased at the end of the second cycle, which students' mathematics result has been in high category. With a percentage of classical completion in cycle II $\geq 85 \%$ of students achieved grades above 65 which was $89.47 \%$. For students' mathematics interest has been more than $80 \%$ that is reaching the expected target. Students' mathematics interest after studying with online-based flipped classroom model achieved the expected target with the percentage of classical completion for student learning interest $\geq 80 \%$ of students have a high and very high learning interest after being given $94.5 \%$ learning.

\section{ACKNOWLEDGEMENTS}

The study is funded by Universitas Bina Bangsa in 2020. Therefore, we express our gratitude and appreciation for the trust that has been given.

\section{REFERENCES}

Akçayır, Gökçe, and Murat Akçayır (2018). "The Flipped Classroom: A Review of Its Advantages and Challenges." Computers and Education 126 (August): 334-45.

Ayçiçek, Burak, and Tugba Yanpar Yelken. (2018). "The Effect of Flipped Classroom Model on Students' Classroom Engagement in Teaching English." International Journal of Instruction, 11 (2): 385-98.

Boriri, Agus, and Yuliani Ishak. (2020). "Relationship between Students' Learning Interests with Their Language Learning Achievement." Langua: Journal of Linguistics, Literature, and Language Education, 3(1): 38-44.

Cheng, Li, Albert D. Ritzhaupt, and Pavlo Antonenko. (2019). 67 Educational Technology Research and Development Effects of the Flipped Classroom Instructional Strategy on Students' Learning Outcomes: A Meta-Analysis. Springer US.

Dina, Zinatun Hayati, M Ikhsan, and Hajidin, H. (2019). "The Improvement of Communication and Mathematical Disposition Abilities through Discovery Learning Model in Junior High School." JRAMathEdu (Journal of Research and Advances in Mathematics Education) 1(1): 11-22.

Elmaadaway, Mohamed Ali Nagy. (2018). "The Effects of a Flipped Classroom Approach on Class Engagement and Skill Performance in a Blackboard Course." British Journal of Educational Technology, 49(3): 479-91.

Ernest, Paul. (2019). "A Theoretical Inquiry into the Ethics of Mathematics Teaching." Malikussaleh Journal of Mathematics Learning (MJML) 2(2): 68-75.

Istikomah, Endang, and Astri Wahyuni. (2018). "Student's Mathematics Anxiety on The Use of Technology in Mathematics Learning." JRAMathEdu (Journal of Research and Advances in Mathematics Education) 3(2): 69. 
Itqan, Moh Syadidul. (2018). "Pendekatan Game Android Untuk Meningkatkan Minat Belajar Matematika Siswa Sekolah Dasar.” Jurnal EduMatSains 2(2): 161-70. http://ejournal.uki.ac.id/index.php/edumatsains/article /view/604.

Korhonen, A. M., S. Ruhalahti, and M. Veermans. (2019). "The Online Learning Process and Scaffolding in Student Teachers' Personal Learning Environments." Education and Information Technologies 24(1): 755-79.

Kusuma, Jaka Wijaya; , and Hamidah, H. (2020). "Perbandingan Hasil Belajar Matematika Dengan Penggunaan Platform Whatsapp Group Dan Webinar Zoom Dalam Pembelajaran Jarak Jauh Pada Masa Pandemik Covid 19." JIPMat 5(1).

http://journal.upgris.ac.id/index.php/JIPMat/article/view/59 42.

Kusuma, Jaka Wijaya, and Hamidah, H. (2019a). "Kolaborasi ModelAssurance-Relevance-Interest-Assessment-Satisfac tion Dengan Think-Talk-Write Untuk Meningkatkan Motivasi Berprestasi Dan Kemampuan Berpikir Kritis Siswa." GAUSS: Jurnal Pendidikan Matematika 2(2): 24. http://e-jurnal.lppmunsera.org/index.php/gauss/article /view/1777.

Kusuma, Jaka Wijaya, and Hamidah, H. (2019b). "Pengaruh Model Pembelajaran ARIAS Dan Cooperative Script Terhadap Minat Dan Hasil Belajar Matematika." ANARGYA: Jurnal Ilmiah Pendidikan Matematika 2(1). https://jurnal.umk.ac.id/index.php/anargya/article/vie w/3460.

Mirlanda, Ela Priastuti, Hepsi Nindiasari, and Syamsuri Syamsuri. (2020). "Pengaruh Pembelajaran Flipped Classroom Terhadap Kemampuan Penalaran Matematis Ditinjau Dari Gaya Kognitif Siswa.” Prima: Jurnal Pendidikan Matematika 4(1): 11.

Mulenga, Eddie Mumba, and José María Marbàn. (2020). "Social Media Usage among Pre-Service Secondary Mathematics Teachers in Zambia." JRAMathEdu (Journal of Research and Advances in Mathematics Education) 5(2): 130-47.

Naserly, Mursyid Kasmir. (2020). "Implementasi Zoom, Google Classroom, Dan Whatsapp Group Dalam Mendukung Pembelajaran Daring (Online) Pada Mata Kuliah Bahasa Inggris Lanjut.” Jurnal AKSARA PUBLIC 4(2): 155-65.

Negara, Habib Ratu Perwira et al. (2020). "Computational Modeling of ARIMA-Based G-MFS Methods: Long-Term Forecasting of Increasing Population." International Journal of Emerging Trends in Engineering Research 8(7): 3665-69.

Panigrahi, Ritanjali, Praveen Ranjan Srivastava, and Dheeraj Sharma. (2018). "Online Learning: Adoption, Continuance, and Learning Outcome-A Review of Literature." International Journal of Information Management 43(July 2016): 1-14.

Riyanda, Afif Rahman, Kartini Herlina, and B Anggit Wicaksono. (2020). "Evaluasi Implementasi Sistem Pembelajaran Daring Fakultas Keguruan Dan Ilmu Pendidikan Universitas Lampung." Jurnal IKRA-ITH Humaniora 4(1): 66-71.
Rizqulloh, Ridho. (2020). Artikel Review Tentang E-Learning Dan Pembelajaran Jarak Jauh (PJJ) Saat Masa Pandemi.

Saifuddin, Much Fuad. (2017). "E-Learning Dalam Persepsi Mahasiswa." Varia Pendidikan 29(2): 102-9.

Triarisanti, Risa, and Pupung Purnawarman. (2019). "The Influence of Interest and Motivation on College Students' Language and Art Appreciation Learning Outcomes." International Journal of Education, 11(2): 130.

Tsai, Ya hsun, Chien hung Lin, Jon chao Hong, and Kai hsin Tai. (2018). "The Effects of Metacognition on Online Learning Interest and Continuance to Learn with MOOCs." Computers and Education 121: 18-29.

Vermana, Listy, and Fazri Zuzano. (2018). "Peningkatan Hasil Belajar Persamaan Diferensial Mahasiswa Pendidikan Matematika Dengan Model Pembelajaran Flipped Classroom." EDUMATICA - Jurnal Pendidikan Matematika 8(2): 23-34.

Wayan Ilia Yuda Sukmana, Adrianus I, and I Kadek Suartama. (2018). "Pengembangan Mobile Learning Berorientasi Model Pembelajaran Flipped Classroom Pada Mata Kuliah Multimedia." Journal of Education Technology 1(2): 45-50.

Wong, Jacqueline et al. (2019). "Supporting Self-Regulated Learning in Online Learning Environments and MOOCs: A Systematic Review." International Journal of Human-Computer Interaction 35(4-5): 356-73.

Yani, Muhammad, and Fatemah Rosma. (2020). "Improving Students' Spatial Ability by Using Macromedia Flash on Geometry Materials." Malikussaleh Journal of Mathematics Learning (MJML) 3(1): 18.

Yuliawati, Neni. (2019). "Peningkatkan Minat Dan Hasil Belajar Matematika Materi Penyajian Data Melalui Model Pembelajaran Kooperatif Tipe Two Stay Two Stray (TSTS) Pada Siswa Kelas VII Mts Muhammadiyah 02 Karanggede Kab. Boyolali Tahun Ajaran 2018/2019." IAIN Salatiga. 